\title{
THROUGH A LENS DARKLY: THE LIFE AND FILMS OF JOHN ALTON
}

\author{
Todd McCarthy
}

"Black and white are colors," John Alton has stated, and no cinematographer in film history has more deeply explored the value of those colors, or the nature of the violent contrast between them, than has John Alton. "I could see more in the dark than I could in color," he claimed, "I could see in the dark." His remarkable talent lay in the way he enabled audiences to do the same.

At the same time, Alton displayed a remarkable ability-intentional or not-to enshroud his career in mystery. He was the Greta Garbo of Hollywood cameramen, an Austro-Hungarian nearly as illustrious in his own field as the great Swede was in hers and, as the years passed, possibly even more mysterious and elusive. After he abruptly quit the industry in 1960 at age 59 , he was rumored to have abandoned cinema for painting, and to be living in Switzerland, Patagonia, or even Hollywood. He refused all requests for interviews or to be a guest at film festivals. The image grew of a ferocious artistic purist who would tolerate no intrusion upon his privacy or the sanctity of his vision.

As it happens, Alton is decidedly an artistic purist, but is ferocious only in the tenaciousness with which he expresses his ideals and opinions. A Middle European charmer and bon vivant even at 92 , Alton has proven to be the most disarming and congenial of guests since, in 1993, he finally reemerged into the public eye at film festivals and special screenings. This process of reacquaintance with cinephiles now continues with the long-overdue republication of his classic 1949 book, Painting With Light, the first book on the art of cinematography ever written by a leading Hollywood cameraman. This event, along with the groundswell of attention Alton has been receiving, represents a happy confirmation of this volume's original epigraph: "Life is short, but long enough to get what's coming to you."

For too many years, Alton was one of the private pet obsessions of a handful of film buffs and critics; those who even knew his name and could cite a few of his credits belonged to a sort of secret society, a shadowy inner circle within the already exclusive coterie of specialists in film noir. Yet, over time, such films as T-Men, Raw Deal, He Walked by Night, Border Incident, and The Big Combo gradually developed wider followings and their striking style began asserting an influence on contemporary filmmakers. Recognition started with the cults surrounding Anthony Mann and Joseph $\mathrm{H}$. Lewis, but finally it became clear that even these directors' other films didn't look like this, that the essence, and ultimate example, of film noir style was, logically enough, created by a cinematographer, not a director.

Considerable academic study has been devoted to film noir in an attempt to define it, describe its parameters, and explain it sociologically, historically, and artistically. But no matter whom one credits with having set the tone for noir-hard-boiled crime writers such as 
Chandler, Cain, and Hammett; expressionisticminded, predominantly Germanic émigré directors, including Lang, Wilder, Siodmak, and Preminger; economy-minded executives and producers looking for tough, timely material that could be done on the cheap; or the politicians of the postwar, Red Scare era who helped foster a paranoid cultural climate-there can be no doubt that John Alton pushed film noir to its most exciting visual extremes. In the definitive noir period, roughly 1946-1951, no one's blacks were blacker, shadows longer, contrasts stronger, or focus deeper than John Alton's. In fashioning the nocturnal world inhabited by noir's desperate characters, Alton was ever consistent and imaginative in forging his signature, illuminating scenes with single lamps, slanted and fragmented beams and pools of light, all separated by intense darkness in which the source of all fear could fester and finally thrive. Alton's films are paradoxically filled with violent killings and relatively absent of kinetic action, largely because his sculpted style demanded a choreography of shots different, and more static, than the norm. Very often, the brightest object in the frame would be located at the furthest distance from the camera, in order to channel viewer concentration; often, the light would just manage to catch the rim of a hat, the edge of a gun, the smoke from a cigarette. Actors' faces, normally the object of any cameraman's most ardent attention, were often invisible or obscured, with characters from T-Men to, perhaps most memorably, The Big Combo playing out their fates in silhouette against a witheringly blank, impassive background. Few, if any other, cinematographers' styles could be said to express a philosophy, a concrete view of the world, but Alton's certainly represents the purest visual correlative for fatalistic existentialism yet seen in motion pictures.

I came to know John Alton as a result of my work on the documentary Visions of Light: The Art of Cinematography. Unable to locate Alton to interview him, my collaborators and I none- theless devoted a section of the film to Alton's work. When he heard about the film, he wanted to see it, and since then I have had the privilege of spending considerable time with him at private screenings of his own pictures, many of which he was seeing for the first time in decades; at the Telluride Film Festival, where I helped present the first tribute to Alton's work attended by the artist himself (Fig. 1); and at his apartment in Beverly Hills-which is dominated by a few of his own paintings, some photographs, and his Oscar for An American in Paris-where he patiently and vigorously answered my many questions about his life and career.

John Alton began his long, accomplished, and exceedingly well-traveled life on October 5, 1901, in Sopron, a Hungarian village near what is now the Austrian border. The family name at the time was the German Altman, although Herr Altman's father undoubtedly had a different surname before moving to Vienna from Russia. John's father Sam Altman, who was born in 1872, and his brother Emile emigrated in the 1880 s to the United States, where they changed their names to Alton and became U.S. citizens, thereby giving John Alton an American connection long before he was born. Emile stayed, but in time Sam retumed to Vienna, where he reclaimed the Altman name and became a brandy, wine, and champagne maker and exporter. For a time, he worked for the wealthy Szecheny family, and it was in the Szecheny castle, where the Altmans had rooms, that John (or Jacob in German, or Janos in Hungarian) was born.

The family had a strong Jewish identity. Sam's wife, whom he had met through a traditional matchmaker, was a Sephardic Jew named Eva Lipschutz, a descendant of a prominent family that had fled Spain for Austria during the Inquisition. For his part, Sam was an adherent of the Austro-Hungarian Zionist leader Theodor Herzl. "My father was a Zionist all his life, on the religious end," Alton recalled. "He was Orthodox, and I didn't agree with all that. $\mathrm{He}$ 


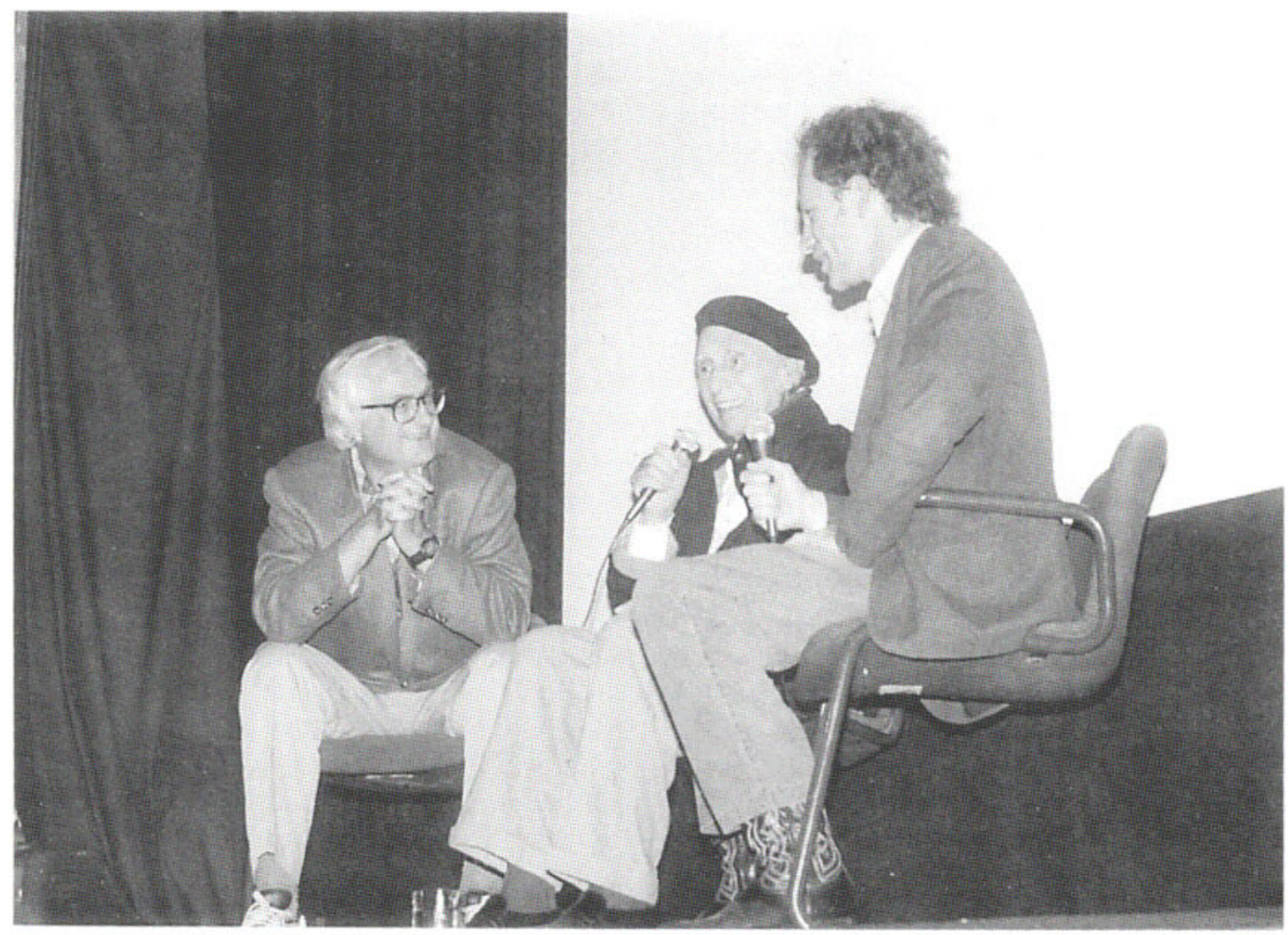

Fig. 1 Filmmaker Bertrand Tavernier, John Alton, and Todd McCarthy during audience discussion at 1993 Telluride Film Festival. Photograph (0) Wendy H. Smith, courtesy of Telluride Film Festival.

spoke Hebrew as a boy, so when he got to Palestine he was able to start making speeches right away."

John's native language was "Viennese dialect" German, but he also grew up learning Hungarian and Romanian (a list to which he later added English, Spanish, French, Italian, and a smattering of other tongues). When the boy was four, the family moved to Transylvania, and subsequently Sam opened his own winery in Romania. A precocious kid, John displayed an artistic bent, taking up photography at age five, learning to develop his own film, and drawing constantly. "In school, I was very bad in most subjects, but very good in drawing and art," Alton said. There were six Altman children. The eldest son Michael "was artistically inclined, but my father killed the artist in him, so he became a bookworm and was not very successful," John recalled. "My father caught the bug of money in America, and he tried for the rest of his life to make everyone American." The second son, Bernard, "was the smartest and most educated of the children. He studied philosophy and was in the German Army in World War I. But later he stayed too long and the Nazis got him and killed him." A daughter, Anna, was next, followed by John, son Harry, and daughter Esther.

Just young enough to miss military service in World War I, Alton attended college for two years. But, as he put it, "I didn't see my future in Hungary." Feeling there were few opportunities for Jews in top professions, and always fascinated by the stories of America told by his father and uncle, he decided to take a chance 
and go to New York, which he did by freighter in 1919. His mother had died in surgery in Vienna in 1914, and after leaving for America, Alton never saw any of his family again except for his younger sister Esther, whom he visited at her home in Israel last year.

Initially welcomed by Uncle Emile, who by this time was the wealthy owner of a Second Avenue furnishings company, Alton enrolled in school (he has remembered it on different occasions as New York University and City College), where he studied photo-chemistry, among other things. It was during this period that John Alton had his first contact with the professional motion picture industry. Living in the Yorkville section in the East 80 s, Alton was "on the bus on Second Avenue when it passed the Cosmopolitan Studios owned by Hearst. I decided to look into it and skip a couple of days of school. So I got off the bus and went up and the man at the gate said, 'You're just the man we're looking for,' and put me in a coat before I could turn my head. After three days, they gave me a check for $\$ 10.50$. Suddenly, I felt rich. Comes the end of the day, and they read the roll of who's going to be called the next day. I felt I had to go back to school, but then I decided, school can wait. In a few days, we went on location. I had to ride a horse-I'd never ridden a horse, except for a merry-go-round horse. I ended up working for 41 days in a row on location, and I pulled in so much money I thought I had it made." Alton could only recall the film as a Marion Davies silent, but the experience was pivotal: "I fell so in love with the possibilities of what I saw in motion pictures."

Alton's windfall didn't last forever, and Emile, a hard-nosed businessman, was not impressed with his nephew's intellectual interest in the fine arts or his vague career ideas, and refused to help him financially. "Every time we sat down to lunch, he was telling me how much money he had made that week, and I didn't care for it." Finally, they clashed irrevocably, and the young man moved out.

Forced to fend for himself, Alton got his first real job at the Paramount Studios lab in Long Island City. When he had earned enough money, he bought a car and, in the winter of 1923-1924, caravaned with five friends across the country. After their arrival in Los Angeles, Alton remembered, they attended the premiere of Douglas Fairbanks' The Thief of Bagdad, which opened at the Egyptian Theater in Hollywood on July 10, 1924. "When I saw it, I started to dream about pictures again, although I had no idea I was going to be a cameraman. There was a fortune-teller for everyone who bought a ticket. She told all the others to go back where they came from. But when I got there, she looked at my palm and said, 'You're going to be a success in pictures.' The rest of them did go back.

"I went to MGM and got a job in the lab, based on the experience I had in New York. When I was there, I gave them ideas, and whenever I gave them ideas, I was fired. But what they forgot was that, in the afternoon, I worked in a different department at the same studio." Despite his occasional run-ins with superiors, Alton gained in-depth experience in various areas that proved tremendously valuable to him when he finally became a cinematographer. In the lab, he became intimately acquainted with the fine points of printing. Transferred to the camera department, he became a loader, and later a first assistant (although he was never an operator). Particularly memorable to him was the opportunity to observe Erich von Stroheim throughout the production of The Merry Widow. However, far more influential on Alton's own later work habits was director Woody S. Van Dyke, for whom he toiled on numerous Tim McCoy Westerns in 1926-1927 as assistant to cameraman Clyde de Vinna. Van Dyke, whom Alton liked enormously, taught him how to shoot quickly and work economically, traits that bcame Alton's bread and butter fifteen years later.

Feeling he was ready to be a first cameraman, Alton said that he went to Louis B. Mayer to ask for his promotion. Although his claim 
seems highly questionable given the fact that most cinematographers at the time were U.S.born, Alton's version of the meeting is amusing. "Mayer said that all the top cameramen had European accents, and that as long as I had my Brooklyn accent, I'd never become a cameraman. So I worked at recultivating my old accent so that, when I came back, I could get a job."

Instead, studio manager Joe Cohn gave the 26-year-old Alton the enviable assignment of accompanying Ernst Lubitsch and another cameraman, Al Lane, to Europe to shoot backgrounds for Old Heidelberg, which subsequently became The Student Prince. When he returned to Culver City, he discovered that this job had caused resentment among some of his camera department colleagues, something that was to plague him at MGM throughout his career. Alton said that Cohn shortly sent him back to Europe to take footage of the 1928 Winter Olympics in Switzerland for potential use in a Garbo picture, although the truth of this is impossible to confirm since no Garbo film features such a backdrop. Similarly questionable is Alton's recollection of a job with director George Hill shooting location material in Algeria and Morocco; none of Hill's subsequent films had desert settings.

Landing in Paris in 1928, Alton claims to have made a discovery that did neither him nor MGM any good, but which proved highly fortuitous for his friend Lubitsch and the history of musicals. In a club in Pigalle, Alton was vastly entertained by a young singer by the name of Maurice Chevalier, who was already known in France but not in the United States. Alton enthused to Irving Thalberg, who happened to be in Paris on his honeymoon with Norma Shearer, and asked permission to make a test. “Thalberg said, 'Go ahead,' so I did, and it turned out pretty well. I sent it to Thalberg at his hotel, and he said, 'This guy hasn't got anything.' I had some friends at Paramount, and Paramount looked at it, signed him up, and made a fortune."

Over the next couple of years, heading the camera department of the Joinville Studios in Paris, Alton shot shorts and other material for MGM and Paramount throughout Europe, in Turkey, and Asia Minor, as well as foreign versions of films in different languages.

To make sure that his colleagues in Hollywood knew that he was gainfully employed and brimming with ideas and ambition, Alton began contributing regularly to the journal International Photographer in 1930. A letter from Stamboul announced his forthcoming location trip to Syria, Palestine, and Egypt, and later dispatches related his experiences working on such 1931 productions as E. W. Emo's Better To Laugh, A. Mitler's Port Said, and Curtis Bernhardt's Der Mann, Der Den Mord Beging (The Man Who Murdered), on which he shot exteriors in Istanbul and experienced an increasing estrangement from the director.

At the beginning of the sound era, the Argentine film industry, which had enjoyed boom years for a decade after World War I, had come to a total standstill. Technically behind the United States and Europe in producing talking pictures, the country needed experienced hands. Strangely enough, John Alton was their man. "I met some Argentine millionaires"-one of whom was the chief financier of the Buenos Aires opera and other theatrical interests-"who were planning to build a studio in Argentina," Alton recalled. "They asked me to come design it for them, so I asked for one-year leave-ofabsence from Joinville. I went to Argentina, we built a studio and I made one film. But in the meantime I got married."

Thus began the most curious, and least known, episode in Alton's life. In 1932, Alton sailed for Buenos Aires and, on five acres thirty miles outside the city in the town of San Ysidro, he supervised the construction of the S.A. Radio-Cinematografica Lumiton (Light and Sound) Studio. He stayed on to train the crew as part of his deal. "I did everything. They didn't know what a propman was, so I had to show them. I had to set up the lab." Alton no doubt remained in Argentina so much longer 
than he originally planned in large part because of his marriage to Rozalia Kiss. A writer for the newspaper La Nacion and a college-educated former beauty contest winner, Kiss interviewed the eminent visitor on board his boat upon its arrival after a 31-day voyage from France. They had dinner that night, and after two weeks were planning a wedding, which took place on November 5, 1932. Originally from an Austrian Jewish family, Kiss was also an early Argentine aviator, but after one hair-raising flight with her through the Andes to Chile, Alton asked Kiss to give up her hobby. They remained married until her death 55 years later.

Late in 1932, Alton photographed what appears to have been the first Argentine talkie, Los Tres Berretines (The Three Buddies), for Lumiton. Directed by Enrique T. Susini, this energetic, carefree comic drama about numerous young people, some of whom are musicians, begins with strikingly evocative street footage of contemporary Buenos Aires to the accompaniment of a wonderful jazz score. As the aspiring working class characters make the rounds through the mostly natural locations of parks, a music conservatory, cafes, a soccer stadium, and other hangouts, one is reminded by turns of Renoir's early 1930s naturalistic human dramas and the speedy, topical, common-people quickies Warner Brothers was turning out at the same time (even including an exceedingly limp-wristed Franklin Pangbornesque gay character). On the outdoor locations, Alton's work is simple and lovely, as he makes his newly adopted city look like a bygone urban paradise, a Paris or Rome in a more tropical setting. Some of his interiors are stunning: At this early date, he was already using slatted and pooled lighting and out-of-the-ordinary facial sculpting; the film's best single shot has a pianist at a grand piano silhouetted in the foreground with several female dancers practicing in the background and bathed in white light. Another scene employs a startlingly noir-like setup as two characters interrogate a third person with a single bulb illuminating them from overhead.
Over the next six years, Alton, by his own estimate, photographed 25 films in Argentina, although it remains difficult to verify the number as a reliable and comprehensive history of the South American film industry has yet to be written. The Fundacion Cinemateca Argentina has been able to authenticate no more than a dozen titles that were definitely shot by Alton, and possesses prints of just six (the Argentine industry and government having been lamentably lax in preserving their output). In addition, Alton directed, coproduced, and/or cowrote a few more.

In 1932, Alton also turned out his first effort as a director, El Hijo de Papa (Papa's Boy), on which he was also tecnico de luz, or lighting technician. This "gaucho film" performed extremely well commercially, although no prints exist because leading man Luis Sandrini so disliked the picture that he bought the negative and all prints and destroyed them. Unlike most people in film, Alton was not seduced by the notion of a directorial career and, in an article for the July 1934 issue of International Photographer entitled "The Cameraman as Director," he made some apt points about the differences between the two jobs. Stating that the camera department is "a place where there is more directorial talent hidden than any other place in the world," Alton, writing from Argentina, noted that, "Many of the few cameramen here have been given a megaphone and failed as directors. But why? They failed because they remained cameramen. They kept on worrying about the photography, ordering lights, etc., thereby driving both cameraman and the gaffer absolutely crazy. The result? That the picture was neither photographed nor directed.

"It is contrary to reason to photograph and direct simultaneously. The new director must forget that he ever was a cameraman. . . . It is for the director to see that the author's mind, spirit, and thought are faithfully reflected upon the mind of the audience. This is an extremely difficult task and far from what the cameraman should concentrate upon." Or, as he elaborated 
the different roles in Painting With Light, "The director sees it as a picture, divided into sequences and scenes, creating in his mind the characters and the dialogue, and worrying about music, sound, and editing . . . The director of photography visualizes the picture purely from a photographic point of view, as determined by lights and the moods of individual sequences and scenes. In other words, how to use angles, set-ups, lights, and camera as means to tell the story." In 1994, Alton simply stated that, "I didn't become a director because every time I looked at a scene, I saw the light on the actors' faces, and didn't hear what they were saying, so I knew I wasn't going to be a good director."

Lumiton was on its way, and remained one of the country's principal studios as the local industry boomed through the 1930s. But Alton, having put it on its feet, accepted an invitation to set up another studio, Argentina Sono Film. By 1939, a year during which some 50 films were being produced in Argentina, Sono had become the country's leading film company, with Alton as its number one cinematographer.

In addition to Los Tres Berretines, I have been able to see four other films Alton shot in Argentina. Amalia, directed by Luis Moglia Barth in 1936, with cinematographer "Juan Alton" receiving a huge credit onscreen, is a mostly stiff drawing room costumer set in 1840. Still, if one were given only one guess as to who photographed the dazzlingly dark night scenes that open the picture, one would have to venture Alton's name. The first sequence features several sinister-looking caped figures skulking out of a minimally lit doorway. They then head into a forest, where, in some extremely dramatic high-contrast images, most of them are killed in a violent sword fight with some soldiers. Overall, the film resembles a routine stage-bound Hollywood period drama of the era-not well directed but competently shot.

The film 12 Mujeres (12 Women), also directed by Moglia Barth, in 1939, is a trivial story about the travails of students at a girls' school, graced only by some crisply attractive night scenes. El Matrero (The Outlaw), a gaucho musical, or Argentine Western, directed by Orestes Caviglia, is also of little interest. It tiresomely follows the format of routine American Westerns, and Alton's work is in an atypically pastoral mode.

Still, in 1939, El Matrero was considered one of the most accomplished Argentine pictures yet made and was released in the United States (in Harlem in New York). The same treatment was accorded Puerta Cerrada (Behind Closed Doors), also made in 1939, which is a lavishly appointed costume picture that demonstrates that Alton could easily have passed muster as a cameraman for MGM at the time. A sort of Stella Dallas with songs about a singer whose baby is taken away by the authorities and adopted while she is imprisoned, this is a predictable, glossy affair directed by prominent actor-director Luis Saslavsky. One highlight is a flashback to the singer's love affair in which the visuals strikingly resemble Lee Garmes' gorgeously romantic work in Henry Hathaway's 1935 Peter Ibbetson, with the characters in a park or forest surrounded by petals and trees, all appearing within images that have their edges smudged to heighten the intoxicated atmosphere.

Prior to this, in 1937-1938, Alton had made a trip to Hollywood to purchase equipment to take back to Argentina. He stayed long enough to shoot a Spanish-language version of $\mathrm{La} \mathrm{Bo}$ heme in 10 days for Columbia. "If I were to give myself an award for the most artistic blackand-white photography, this would be it," Alton said. Starring Gilbert Roland and Rosita Diaz under the direction of Joseph Berne, La Vida Bohemia, which happily still exists in $35 \mathrm{~mm}$ nitrate prints, doesn't quite bear out Alton's memory of it, but the lovely, nuanced lighting and compositions of several scenes testify to an exceptional talent behind the camera. In fact, the film is indicative of a tendency found in many of the low-budget, tightly scheduled films Alton was to shoot over the next 10 years: Unavoidably, the majority of scenes have a flat, 
perfunctory, B-movie feel to them, but one can tell that Alton put a tremendous amount of attention, ingenuity, and care into a handful of particularly important sequences, which are so visually powerful that they alone lift the entire film up to a higher level than the norm. In other words, Alton was flexing his muscles and showing what he could do in chosen moments in the subterranean reaches of the world film industry, but mainly because he couldn't help himself-it was his nature to be imaginative and bold.

Looking at La Vida Bohemia again, 45 years after he shot it, Alton still expressed satisfaction with it, although one can intuit that he loves the film as much for its subject as for the quality of his own contributions. "La Boheme is one of my favorite stories about the old days because it's about artists, their struggles, their work," he confessed. Very simply, it's about the kind of person Alton is, and the same could be said of other films he shot, from Los Tres Berretines to An American in Paris. Into his 90s, Alton habitually wears a beret and has the air of a Continental bohemian of the 1920s.

An important fact about Alton, which bears considerably upon his career, is that he was an intellectual among cameramen at a time when this was neither common nor fashionable. Or, as cinematographer John Bailey put it, "He created an aura of the artistic temperment." Although many of the great cinematographers of the studio era, particularly those who came from Europe, were refined and highly knowledgeable about the arts, the accepted personality for a cameraman was to be a tough, gruff, macho boss of a large crew of union technicians and strong men. Alton could be all this, and was certainly forceful in getting what he wanted, but he either would not or could not hide his elevated artistic sensibility, nor his belief that he was more capable than most of his peers. He dressed in an elegant, dapper manner; ate special lunches, prepared for him by his wife; left the studio promptly every evening to join her rather than go out with the boys; and was open about visiting museums and soaking up the lessons of the masters. "Rembrandt was a big influence. Rembrandt's genius was pictorial, and his ideas could be easily adapted to motion pictures. But I learned something from all of them," he recalled.

The one remaining Argentine film shot by Alton that is known to exist is Cadetes de San Martin (The Cadets of San Martin), directed by Mario Soffici in 1937. Among the other missing titles are Crimen a las Tres (Crime at 3 O'clock), directed by Saslavsky, and Escala en la Cuidad, directed by Alberto de Zavalia, both in 1935; Goal, directed by Luis Moglia Barth in 1936; the particularly highly praised Macheselva (Honeysuckle), directed by Luis C. Amadori in 1938 and, the following year, the same director's Caminito de Gloria, which was coshot by Jose Maria Beltran. There was also Saslavsky's 1937 drama La Fuga (The Flight), which may have been shot either by Alton or a German named Gerardo Huttula, but which is known because film critic Jose Luis Borges praised it for its pleasing way of avoiding picture-postcard clichés in its depiction of Buenos Aires and the countryside.

Finally, in 1939, Alton and his wife decided to pull up stakes in Buenos Aires and move to Hollywood, an event heralded in the pages of the November 1939 issue of American Cinematographer with an article entitled "John Alton Returns to Hollywood from Abroad." With the single exception of La Vida Bohemia, Alton had not worked in the United States in more than a decade.

Just prior to this, with war looming in Europe, Sam Altman, his son Michael, and daughters Anna and Esther got out just in time and moved to Palestine, where Sam continued in the spirits business. John's older brothers Harry and Bernard decided to stay in Romania; eventually, Harry escaped, joined the family in Palestine and later enlisted in the army and was killed. Bernard, blindly confident that the Nazis wouldn't bother him because he was a German Army veteran, remained behind and died at Dachau. 
With Hollywood in a boom time, and Louis B. Mayer's vague promises still in the back of his mind, Alton hoped to be able to rejoin MGM upon his return. But he had made a number of enemies at Metro back in the 1920s, one of whom, John Arnold, was now in charge of the studio's camera department. As it happened, Arnold would plague Alton's career for the next 15 years, and effectively block any chance Alton might have had of starting at the top in Hollywood.

Instead, Alton was hired at RKO at the personal request of director Bernard Vorhaus, who was impressed with the South American work Alton showed him. Their first assignment together, starting in January 1940, was on The Courageous Dr. Christian, the second in a successful series of films that starred the venerable Jean Hersholt as a wise rural doctor. These pictures were decent B-movies made in 12 days, and Alton ended up shooting four of the six entries, also including Dr. Christian Meets the Women, Remedy for Riches and Melody for Three. Vorhaus also became one of his most frequent collaborators, as they worked together eight times before Vorhaus was blacklisted and moved to England. (Alton has stated that Vorhaus was named by Ronald Reagan, a close friend of Vorhaus's during the 1940s, a charge Vorhaus now deflects in gentlemanly fashion.)

Vorhaus singled out two main reasons that he loved working with Alton: his speed and his ingenuity. "From a practical point of view, he was incredibly fast," Vorhaus recalled in 1994 from his home in London. "When he shot his first film for Metro, they didn't believe he'd used enough light for exposure, and they went around checking up on him. On The Courageous Dr. Christian we had a crazy schedule, as usual, with one day on the studio lot to shoot all the exteriors. It was getting late and I was afraid we were going to lose the light before we finished everything we needed. But John said, 'As long as we don't show the sky, we can shoot it after dark, it won't matter.' And we did it at dusk and it looked just like the stuff we'd shot in sunlight.
That was the first time anyone ever said anything like that to me.

"He was so imaginative, he was very innovative, quite remarkable. I've never known anyone like him. He was so good at getting meaningful effects and dramatic lighting," said Vorhaus, who remembered with affection a greenhouse scene in his 1942 Affairs of Jimmy Valentine into which Alton introduced striking slatted lighing effects.

Alton himself retains one vivid memory of Vorhaus's Three Faces West, a film that is somewhat interesting for its premise--modern cowboy John Wayne leads Austrian refugees to safety away from the Nazis in the American West. Rather than eating in studio commissaries, Alton always had his lunches packed for him by his wife, and he had the habit of eating whenever he happened to get hungry. As he recalled 50 years later, midafternoon one day, he decided to eat his sandwich, and Wayne remarked that it looked good and asked for some. Not giving it a thought, Alton handed it to the actor, who took a bite, only to discover that it was a garlic sandwich. Unfortunately, Wayne was in the midst of shooting a love scene with Sigrid Gurie, who slapped him for his lack of consideration. Wayne was furious with Alton, and never spoke to him again.

Alton worked briefly at Paramount for William Pine and William C. Thomas, B-producers so tight with a buck that they were known as the "Dollar Bills." Their pictures were generally shot in 10 days for under $\$ 100,000$, but Alton kept thriving under this sort of pressure and furthered his reputation as a cameraman who could make a B-picture look like an A production. As American Cinematographer noted of his work on a 1941 quickie, Power Dive, "Alton's treatment of his principals is excellent. His set-lightings are far more pictorial than we usually see on pictures made on any such schedule as this ... In a word, he has not only distinguished himself, but has set a mark for other men who photograph films of this class to shoot at-and envy." 
At the end of that year, the same publication commented that Alton's work on John H. Auer's The Devil Pays Off was "by far the best camerawork we've seen emerge from the Republic Studios," that it was "definitely major studio calibre, combining fine photographic quality with dramatic feeling and pictorial effectiveness." Throughout his tenure in B-pictures, Alton often saw his contributions to otherwise forgettable films singled out for special mention in the Hollywood trade press.

With such praise coming his way, it is unclear exactly why Alton didn't quickly make the jump to major studio work, or at least remain on the level where he started the 1940s, shooting second-level productions at RKO and Paramount, until being promoted. Instead, Alton's professional standing mysteriously diminished. He signed with Republic in late 1941 but was loaned out to lowly Monogram two years later on pictures such as The Sultan's Daughter and the infamous Dr. Goebbels biopic, Enemy of Woman (renamed Mad Lover).

Alton had an interesting military career during World War II. A blurb in American Cinematographer in February 1943 identified him as "Captain John Alton-serving as liaison offcer between the Commanding General's office and the Signal Photographic Laboratories, and his former Commander, Lt.-Col. Edward J. Hardy, under whose command Alton received his basic military training." Hardy was commanding officer of the First Signal Corps Photographic Laboratory, and Alton worked in the lab rather than shooting footage for the government. Certain aspects of his military service remain mysterious: Alton has variously stated that he was stationed throughout most of the war at Fort Bliss in Texas, that he served with General Omar Bradley in Europe, and that he was in demand as a linguist, notably in Egypt and Greece toward the end of hostilities. One report maintains that he was discharged in 1944 for having enlisted when overage, another that he was let go for medical reasons. But Alton's most memorable duties were as "a special courier. I was sent around the world with special confidential mail that they didn't trust to send any other way. It was a great job. I had special planes and special treatment of every kind. I was sent to Rio when the Americans were contemplating an invasion there to combat all the German influence, to Peru, North Africa, Egypt, and the Asiatic countries. And I met some of the big stars and producers everywhere. No matter where I went, all over the world, I met people from Hollywood."

Along with his army service, Alton managed to continue his career apace during the war, lensing five films in 1942, just one in 1943, five in 1944, and three in 1945 . He particularly enjoyed shooting The Lady and the Monster (renamed Donovan's Brain) because it starred Erich von Stroheim and because director George Sherman was almost as fast as he was. Of greater significance, however, was Republic's decision early on to place its recently signed new director, Anthony Mann, in Alton's hands to learn the ropes of filmmaking, a move that would prove of tremendous significance to both men a few years later, even if it never benefited the studio that introduced them.

For seven years, or as long as he had spent in Argentina, Alton bided his time in the B-movies, working well, if anonymously, on films that attracted little interest at the time and have no reputations today. The executives and producers at B-studios liked Alton because of his speed and his ability to give a distinguished look to a cheap product. "I knew in order to exist in this business, I couldn't rely on art," Alton said, "because the producers were not artists. My first job was to win over the man who paid me. So I figured out how. I got $\$ 1,500$ per week, when others were getting $\$ 250$, because of my speed, because they made money with me."

The turning point in Alton's career came in 1947. Early in the year, he photographed W. Lee Wilder's crime drama The Pretender, which at least one critic, Spencer Selby, in his book Dark City: The Film Noir, considers to be 
Alton's first noir; to accommodate Alton's expressionistic intentions and deep-focus lenses, special sets were built with forced perspective. Then Anthony Mann, who had been lurching along in B-movies since 1942, signed on with Eagle-Lion, a small company formed in 1946 and run by future industry titans Arthur Krim and Robert Benjamin. Heading production was Bryan Foy, former chief of the B-unit at Warner Brothers, who had a sharp eye for talent that nicely balanced his commercial instincts. For his new film T-Men (Fig. 2), Mann specifically asked for Alton, who was loaned out by Republic for the job. A hard-boiled crime story about Treasury Department agents trying to bust up a counterfeit ring, the film begins in the semidocumentary manner made fashionable at the time by The House on 92nd Street. But it very quickly plunges into deep noir and stylization through the use of what Alton at the time called "almost 100 percent natural photography." Creating tremendously dramatic images and tense moments by enshrouding much of the action in utter blackness, Alton and Mann didn't invent film noir, but they created some of the most indelible examples of it, pushing the style further than anyone had dared up to that time. "I found a director in Tony Mann who thought like I did," Alton explained. "He not only accepted what I did, he demanded it.

"Other cameramen illuminated for exposure. They'd put a lot of light in it so the audience could see everything. I used light for mood. All my pictures looked different. That's what made my name, that's what set me apart. People asked for me. I gambled. In most cases, the studios objected. They had the idea that the audience should be able to see everything. But

Fig. 2 A scene from T-Men. Print courtesy of the Museum of Modern Art Film Stills Archive.

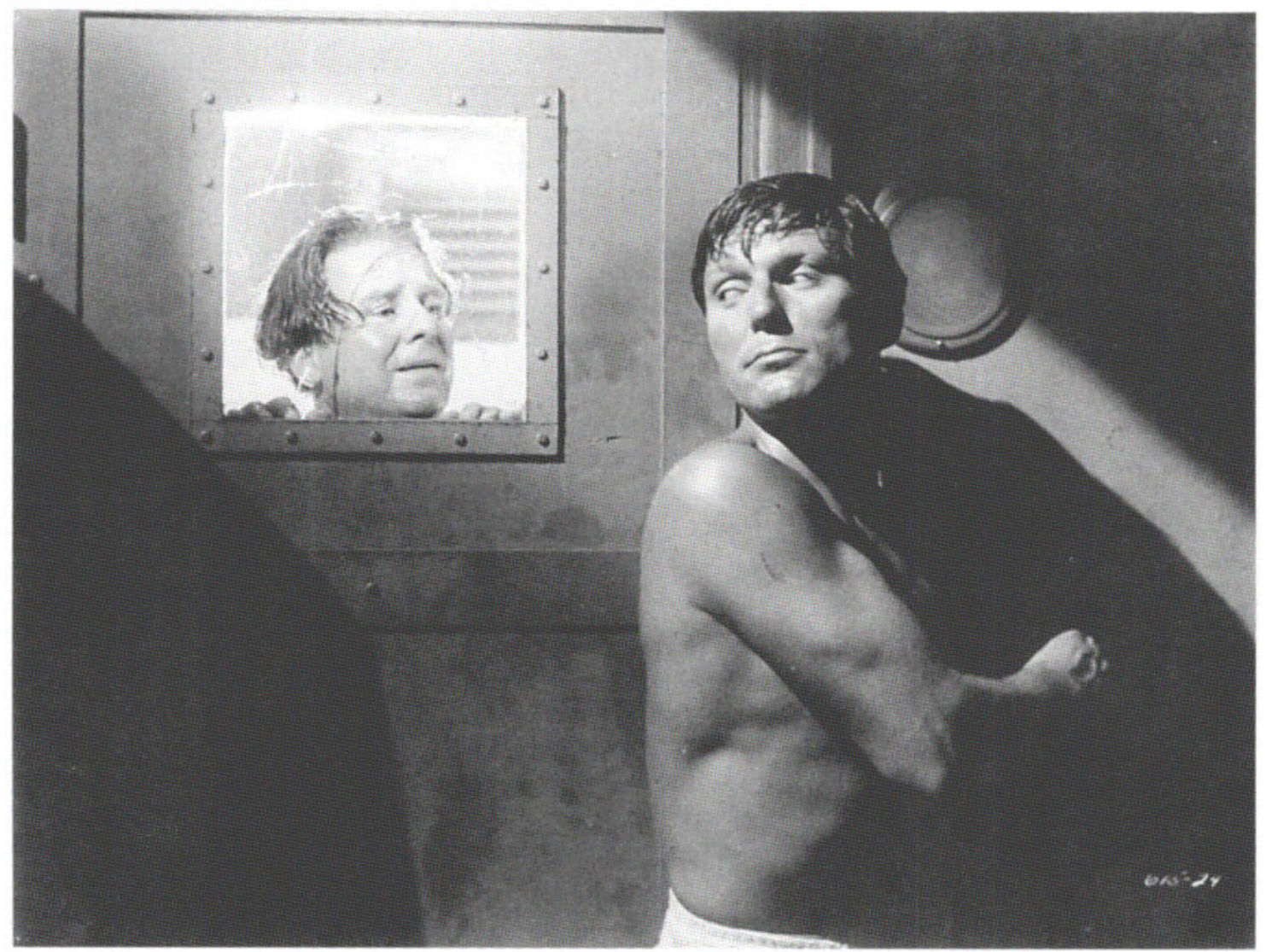


when I started making dark pictures, the audience saw there was a purpose to it."

In the case of $T$-Men, audiences responded in droves, giving Eagle-Lion a major hit on its small investment and making the names of the director and cinematographer in the film industry. Always employable on a certain level, Alton was suddenly in heavy demand. In 1947, he photographed nine films, and the following year he shot five pictures, all examples of film noir in its prime: Crane Wilbur's Canon City, Vorhaus's The Spiritualist (renamed The Amazing Mr. X), Mann's Raw Deal, Alfred Werker's (and Mann's) He Walked by Night, and Steve Sekely's (and Paul Henreid's) Hollow Triumph (renamed The Scar).

Another semidocumentary crime entry, Canon City was filmed only three months after the
Colorado prison break that inspired it (Figs. 3 and 4). The sequences shot on location in the penitentiary are arresting, as Alton took no electricians with him and used only existing light fixtures boosted by stronger than usual bulbs. Unfortunately, the film splinters into a succession of decreasingly effective scenes depicting the assorted escapees hiding out in various families' homes, although Alton's highcontrast touch is readily apparent. Still, the film, which was shot in 19 days, did very well, and was held up as a fine example of what could be done on a low budget.

The Spiritualist, starring Turhan Bey as a phony seer, is a film of modest virtues, but Alton's work in several scenes is remarkable, notably in the dreamily ethereal opening and in the intense mood-setting of Bey's gazes into

Fig. 3 A scene from Canon City. Print courtesy of the Museum of Modern Art Film Stills Archive.

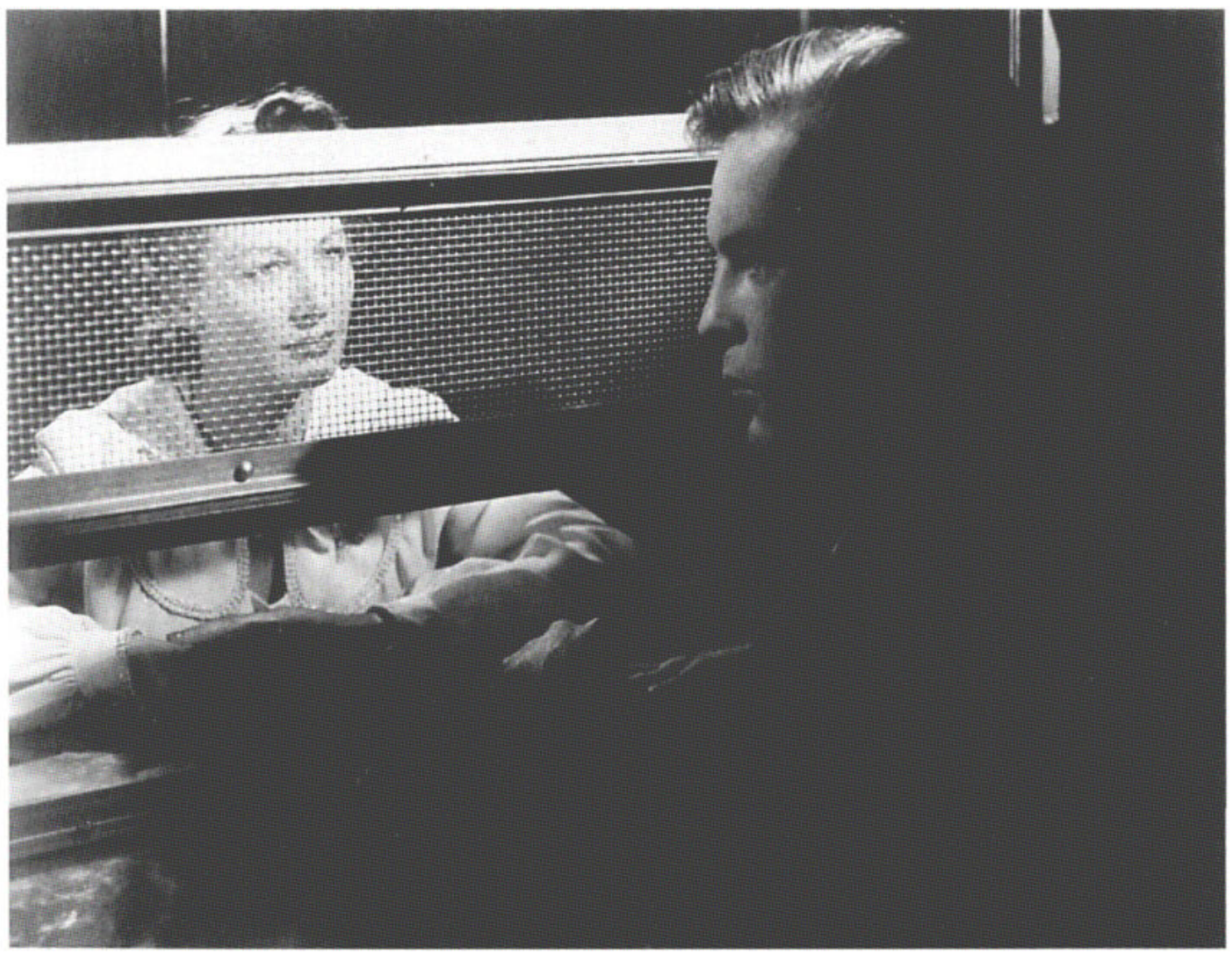




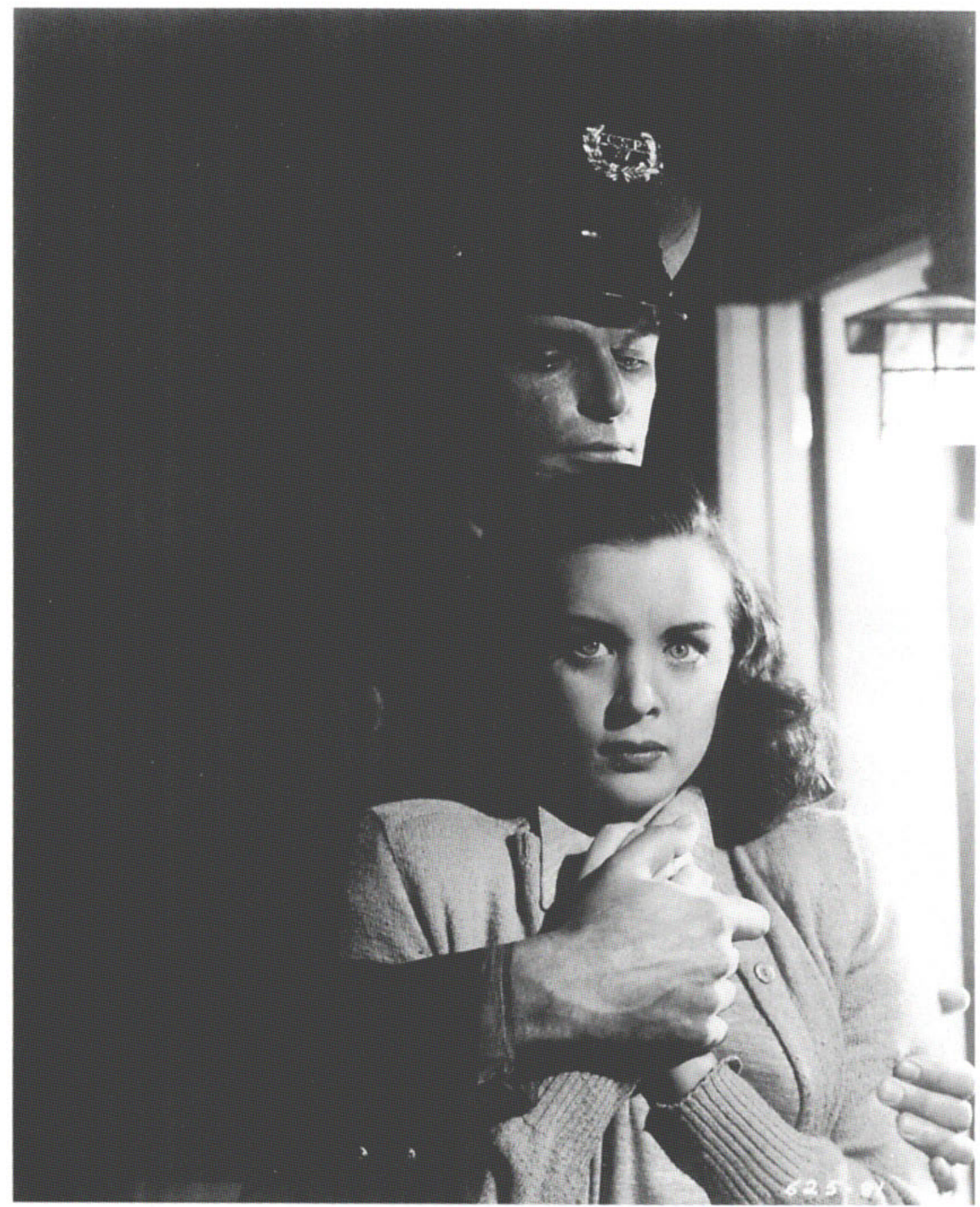

Fig. 4 A scene from Canon City. Print courtesy of the Museum of Modern Art Film Stills Archive. 
characters' personalities and futures, including clairvoyance sessions in which the light emanates directly from Bey's crystal ball. Once again impressed with Alton's daring, Vorhaus recalled that, for a beach scene near the beginning, "We were shooting day for night, and I said to John, 'Suppose we shoot right into the sun and get some glare,' and he said, 'Why not?' It was taboo at that time."

Raw Deal made a worthy, if less dramatically satisfying, companion piece to T-Men, a bleak study of crime and duplicity that features much definitive noir iconography, topped by Raymond Burr's fiery, vertiginous demise (Fig. 5). Less seen today, He Walked by Night was received by critics at the time as the high point of the Eagle-Lion crime cycle. Starring Richard Basehart as a brainy killer on the loose in Los Angeles, the film was coscripted by John C. Higgins, who wrote T-Men and cowrote Raw Deal. Some way into the shooting, the original director, Alfred Werker, was replaced by Mann, and it's not hard to tell what Mann shot: all the night exteriors featuring Basehart, and the astonishing climax in which the killer attempts to elude the enclosing police by slipping through the city's storm water drainage system. Never were Alton's images darker, sharper, or more glistening; his talent for visually conjuring up the unbearable claustrophobia so essential to film noir was at its peak, as was his natural ability for creating compositions that instantly de-

Fig. 5 John Alton, left, on the set of Raw Deal. Print courtesy of the Museum of Modern Art Film Stills Archive.

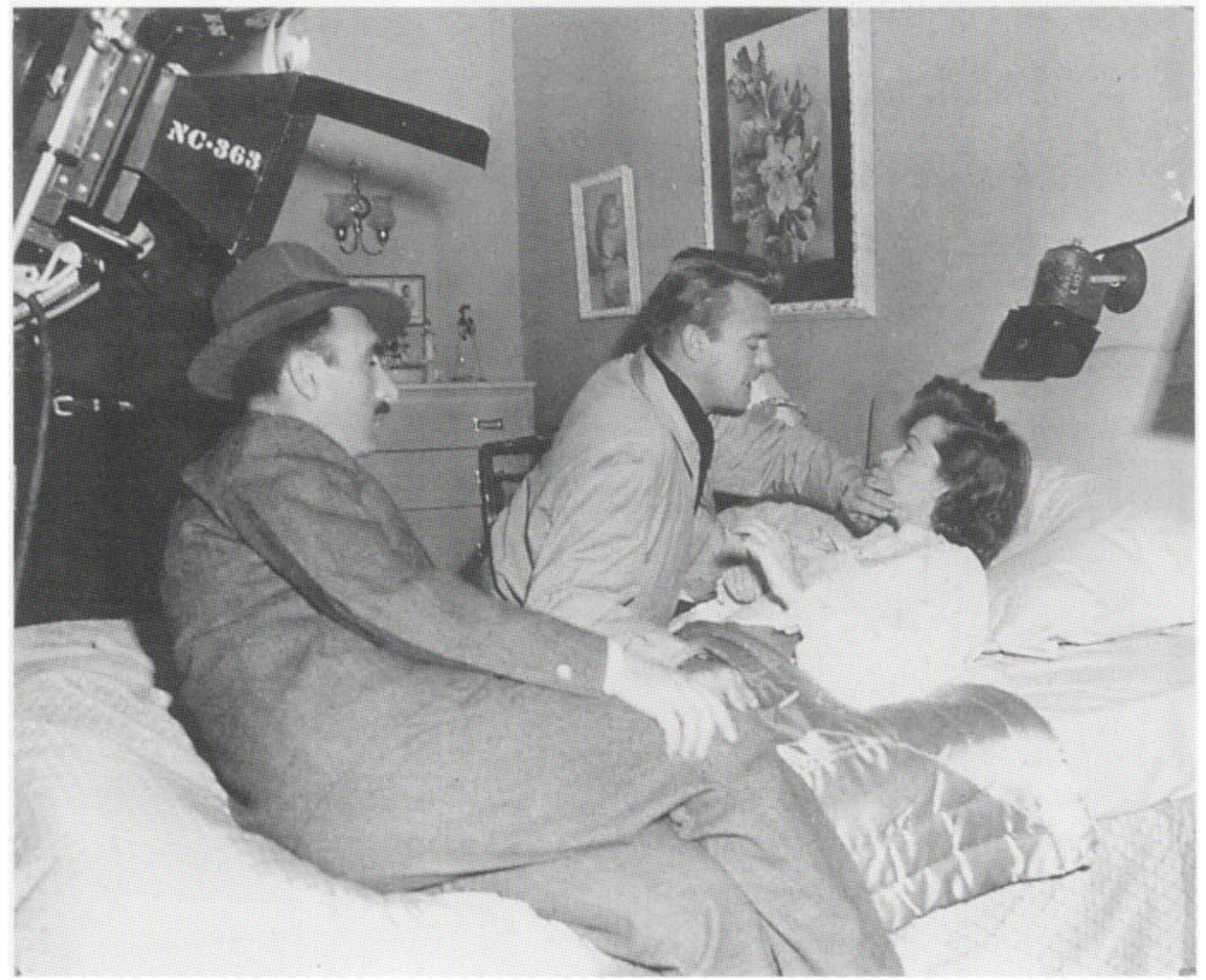


lineated the tension and violent dynamics between characters.

Rounding out this extraordinary year was Hollow Triumph, later retitled The Scar. Daniel Fuchs' script concerned a low-life former medical student who murders and assumes the identity of a psychiatrist to shed his gambling debts, and the original director was Steve Sekely, a fellow Hungarian Alton had known years before in Europe who made some films of passing interest. But partway into the shoot, no one felt that the results were living up to expectations, so, as Paul Henreid explained in his memoirs, the producer-star took over the direction. In any event, Alton added some quintessential images to the noir canon, including a deftly contrasted hotel-room scene between Henreid and his brother, and a chase on foot through downtown Los Angeles that ends up on the late, lamented Angel's Flight tram, one of the key cityscape icons of hard-boiled fiction.

Alton continued working at full throttle, shooting five films in 1949 and six pictures the following year. So pervasive was the cameraman's credit that American Cinematographer felt compelled to report that, "John Alton's life is just one picture after another." In 1949, he lensed one neglected noir, The Crooked Way, a rather low-key crime film directed by excinematographer Robert Florey that is fully up to the contemporaneous Alton standard, as well as his first work in color, Red Stallion in the Rockies, for director Ralph Murphy at EagleLion. Mann's Reign of Terror (later retitled The Black Book) was a bizarre oddity, a drama of the French Revolution shot in all-out noir style. Although it didn't do well, the film represented a triumph of sorts in the way Mann, Alton, and designer William Cameron Menzies overcame extremely limited means through diabolical ingenuity, making cramped sets look resplendent and 30 extras look like 300. Even more crucially, Dore Schary, the former head of production at RKO, visited the set of Reign of Terror at Eagle-Lion and was impressed with the methods of the key creative team. When Schary assumed the production reins at MGM, the first people he hired were Mann and Alton. As it happened, they were in active preparation for Border Incident at the time, and EagleLion, then cash-strapped, was happy to unload the whole project, which accounts for how the harshest, darkest, and most uncharacteristic film ever made at MGM ended up at Hollywood's most prestigious studio.

It also explains how Alton came full circle to wind up as a leading cameraman at the same studio he had left with Lubitsch more than twenty years earlier and which had shunned him when he arrived from South America ten years before. Still, a differing account of the reason for the move was given by studio vice-president Joe Cohn, who was mightily impressed by T-Men and claimed he hired Alton for $\$ 800$ per week, "more money than I was paying any other cameraman. I gave him that salary because I wanted to hire him and he wouldn't work for less, and I wanted to shake up the other cameramen. I thought our cameramen had become too complacent, and I felt we needed a cameraman who would shake the hell out of the place, and I thought Alton could do that for me. In lighting, he saved a lot of time by lighting only from the floor. This made him very unpopular with the other cameramen."

Border Incident, a violent look at illegal immigration from Mexico, was one of Mann and Alton's top achievements, as was the unjustly neglected Devil's Doorway, one of the very first righteously pro-Indian Westerns that suffers today only from the sight of Robert Taylor (in an uncharacteristically fierce performance) playing a half-breed. Mann specifically requested Alton for the picture, and their last collaboration paid off: the cameraman imbued even the expansive exteriors with a sinister quality. A confrontation and fight scene in a barroom also sizzles with low-lit, deep-focus tension within the frame.

Alton continued to contribute to noirish dramas atypical for MGM, such as two John 
Sturges films, Mystery Street and The People Against O'Hara. Because of his on-going dispute with the head of MGM's camera department, John Arnold, Alton was repeatedly leaving and returning to Metro. Alton has described Arnold as the chief nemesis of his career, and he was a bad enemy for a cinematographer to have. A New Yorker who had started his career in the engineering department of the Thomas Edison Company, Arnold then worked for Vitagraph, Biograph, and other companies before joining Metro in 1915. The definition of a company man and an establishment figure, Arnold had been with MGM since its inception in 1924, shot The Big Parade for King Vidor the following year, was chairman of the photographic section of the Academy of Motion Picture Arts and Sciences' technical branch, and was the first and long-term president of the American Society of Cinematographers, which Alton had joined in 1937 but quit (an almost unheard-of act for this honorary group) in 1944 "when Arnold started to be rough with me." This act, Alton admitted, "didn't do me any good later." At MGM, Arnold was referred to as "the policeman" who watched over studio's cinematographers to make sure they didn't deviate from the way things had always been done. Alton, whose style ran so completely contrary to the bright, expensive, highly polished look favored at Metro, claimed that Arnold "hated my guts because I succeeded more than he did. I had made him look bad. Because he was head of the department, he stopped me. He fought me. He tried to fire me every time. I lost pictures for a couple of years because of him, so finally I quit. They had difficulty with my ideas. One day they'd fire me, then I'd go off to do an independent picture to pay the rent, then MGM would hire me again." In the end, Alton outlasted Amold at MGM. "Joe Cohn said to him, 'You use Alton or you're out of here.' Finally, he came to a bad end at MGM, and I was there longer than he was." While both men were at the studio, Alton's trump card was that, no matter what Arnold thought, Alton was not only a favorite of pro- ducers for his speed, but he became the preferred cinematographer of two of Metro's top directors during the 1950s, Vincente Minnelli and Richard Brooks. Alton acknowledged that, "I always fought with the studio and producers, but I was okay when the directors were somewhat artistic and stood up for me," which these two did at MGM. Minnelli asked for Alton on Father of the Bride in 1950 specifically so that he could shoot Spencer Tracy's surrealistic nightmare sequence.

Alton claimed that he turned down Minnelli's next, An American in Paris, but later agreed to shoot the ballet because the painterly inspiration of the extravagant 20-minute sequence inspired his imagination (Fig. 6). The contentious feelings other people at Metro had about John Alton are amply evident in Donald Knox's littleknown book The Magic Factory: How MGM Made "An American in Paris." Published in 1973 , the volume includes oral history testimonies from every key surviving member of the film's creative team-25 in all-except Alton. Minnelli began by pointing out that he wasn't happy with the work of Albert Gilks, who shot the narrative body of the picture, because he considered it terribly overlit. For the ballet, then, "I insisted on using another cameraman ... He was disliked, however, by the other cameramen because he had written a book called Painting With Light. They all thought he was egotistical. But he was so fast and used so few lights. I got along just wonderfully with him. I felt that the ballet needed someone who would live dangerously. We had to take chances because in the ballet there is nothing that was done afterwards in the lab; everything you see was done on the set. So I decided it needed John Alton."

Seconding Minnelli's assessment of Alton was Gene Kelly. "Vincente suggested a lot of the light effects. We'd say, 'Wouldn't this be great?' but often they took a lot of time, because cameramen can get very stubborn. But we found Alton willing to try anything. We'd say, 'Can you do this?' He'd say, 'Yeah, that's 


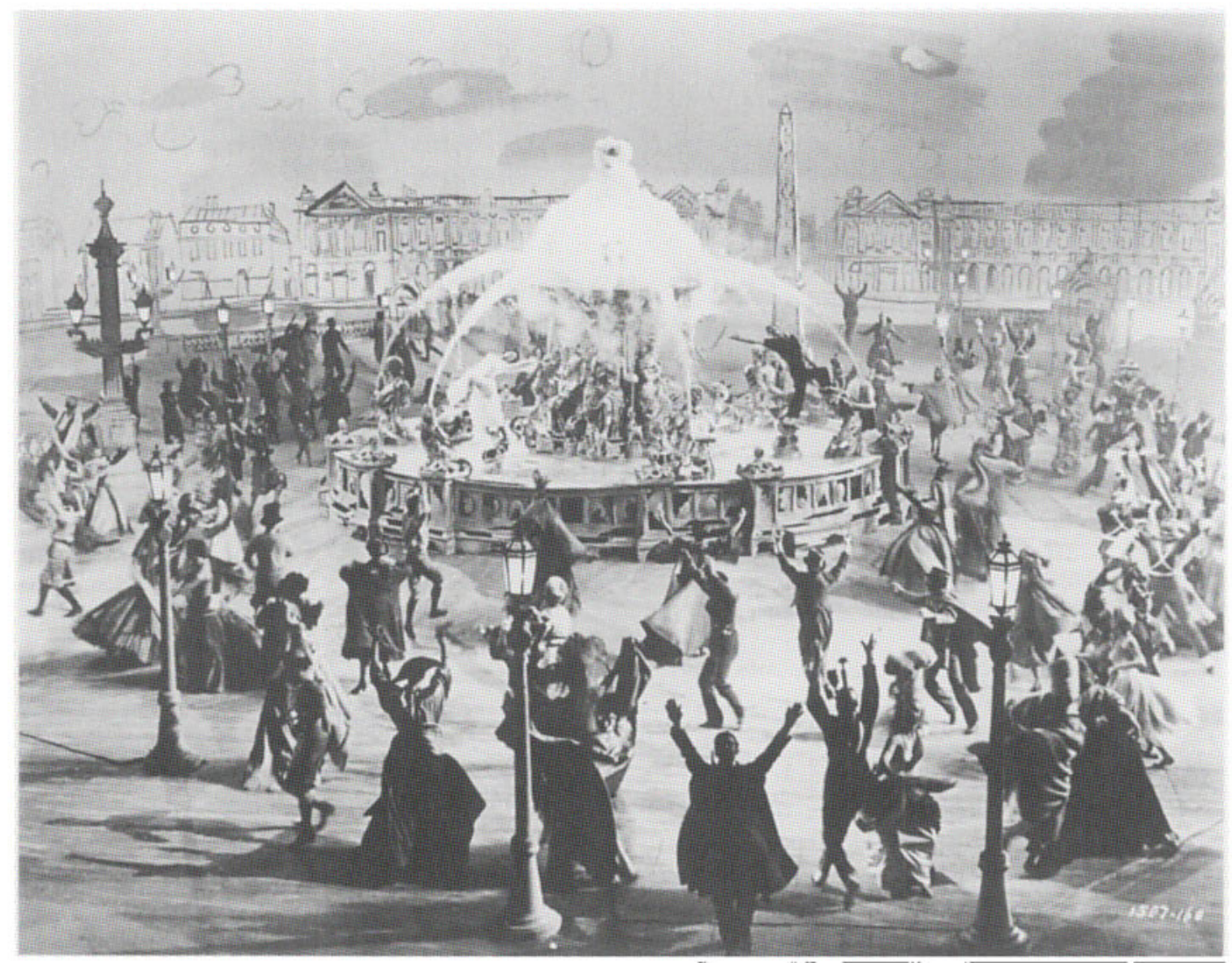

Fig. 6 Ballet sequence from An American in Paris. Print courtesy of the Museum of Modern Art Film Stills Archive.

easy. Yeah.' And for the first few days we were sort of worried because we'd been used to a lot of cameramen saying, 'You guys are nuts. You can't do that.' It seemed that about every picture we'd try something new and the person with whom we'd be working would say, 'No, you can't do that,' because they had never done it before."

The old-line, anti-Alton view was expressed by the film's art director Preston Ames. Describing how difficult it was to create the right look for the ballet's "Van Gogh" set, Ames recalled that, "John Alton, one day, set yellow light filters on all the lights, and he said to Vincente, 'This is the only way you can shoot this thing, you know.' And I looked at him, and I said, 'What are you doing?' And he said, 'Oh, this is the only way it can be done.' So I had to get a hold of Kelly and say, 'Kelly, do you want a bright yellow face when you're dancing?' And I said to [costume designer Irene] Sharaff, 'Do you want this bright yellow light all over your costumes?' She was furious, and there was a battle royal about it, you know: 'Rip those lousy goddamn things off,' and that's what happened. $\mathrm{He}$ started to get smart. He was working his way and not our way, and our way had been studied. He just came on the scene and thought this was very clever. He did the same thing on the next set; he put some purple filters on the Toulouse-Lautrec thing. It was horrible. It was just horrible. But he was painting with light. $\mathrm{He}$ loved to use that expression. This fellow was doing a petty thing, and he was destroying 
everything we had worked months to get, which was the perfect matching of everybody's thing clicking and working together. All of a sudden, he was saying, 'I'm going to show you really how it should be done,' and he loused it up, but royally. We corrected it, and in spite of everything it came out all right, but you had to be very careful that somebody didn't pull a fast one on you and really do things wrong. You just couldn't let them."

Putting some perspective on Alton's position at MGM was the studio's production department head Walter Strohm, who admitted of Alton that, "Most people hated him. They said, 'How can Minnelli put Alton on the ballet?' I said, 'Because he knows how to light.' Believe me, he knew how to light! I'll tell you a director who's difficult to get along with but who was crazy about Alton: Richard Brooks. He thought Alton was just great. Alton had a technique for a production man-and now I'm talking about my side of it-that was very helpful. I know why they didn't like him, and that was the thing that we liked about him most: He had none of this old studio technique. Some cameramen used the same lighting technique every time to light a set, because, the more units they had up there to light with, the more electricians it gave jobs to. Alton didn't give a damn about any of that. He was interested in getting an effect, and he could get an effect like that. He was very fast. Of course, that killed them; he was too fast for them. They didn't like that. He was ready, and the director was left holding the set. $\mathrm{He}$ just said to the director, 'I'm ready.' The director wanted to take two hours while they rehearsed and fussed around, and Alton said, 'No, I'm ready. Anytime you want to."'

No doubt the most ambitious, dramatic, and complex musical number ever staged for an MGM musical, the An American in Paris ballet is a swirling, surprising, constantly changing, beautifully designed, and somewhat overripe 20 -minute piece that clearly benefited from Alton's bold, unconventional lighting schemes. Very proud of his work on the film, Alton said,
"The ballet had nothing to do with the story and a lot to do with lighting. Minnelli helped me a lot with the lighting. I tried out fluctuations of light within the shots. I shot in color, but with black-and-white lighting." Ironically, Alfred Gilks, whom Minnelli had come to hate, and Alton shared the 1951 Academy Award for best cinematography for this movie. After Gilks delivered brief thanks at the Oscar ceremony, Alton had only this to say to the audience: "I wish to thank Mr. Vincente Minnelli for his confidence in our work. Thank you."

In fact, Alton and Minnelli had worked together on another picture immediately prior to filming the ballet, Father's Little Dividend, which, thanks in large measure to the cameraman, was finished in a tight six weeks, an unusually short shoot for Minnelli. Through 1957 they were to collaborate twice more, on the color and Cinemascope Tea and Sympathy and Designing Woman. Alton adored Minnelli. "Somehow we saw things similarly. $\mathrm{He}$ was a designer, and he had New York stage experience, which complemented my motion picture experience."

Despite his Oscar and inside track with producer Arthur Freed and Gene Kelly, Alton didn't fare well on his next assignment. Flush from An American in Paris, Alton was hired to shoot Singin' in the Rain for Freed and directors Gene Kelly and Stanley Donen. But his work on this film satisfied no one and, after two weeks, he was fired, accused of shooting in a way that would not permit the colors to match and cut together shot-to-shot and scene-toscene. Much of his material was reshot.

As punishment, Alton was assigned to Talk about a Stranger, a small feature being directed by a young Dore Schary protégé, David Bradley, who, up until then, had only made amateur versions of classic texts back in Chicago but had also discovered Charlton Heston (Figs. 7 and 8). Bradley had observed Alton at work on the ballet sequence, and was both thrilled and terrified at the prospect of working with the famous cameraman. "I was warned that he'd eat 


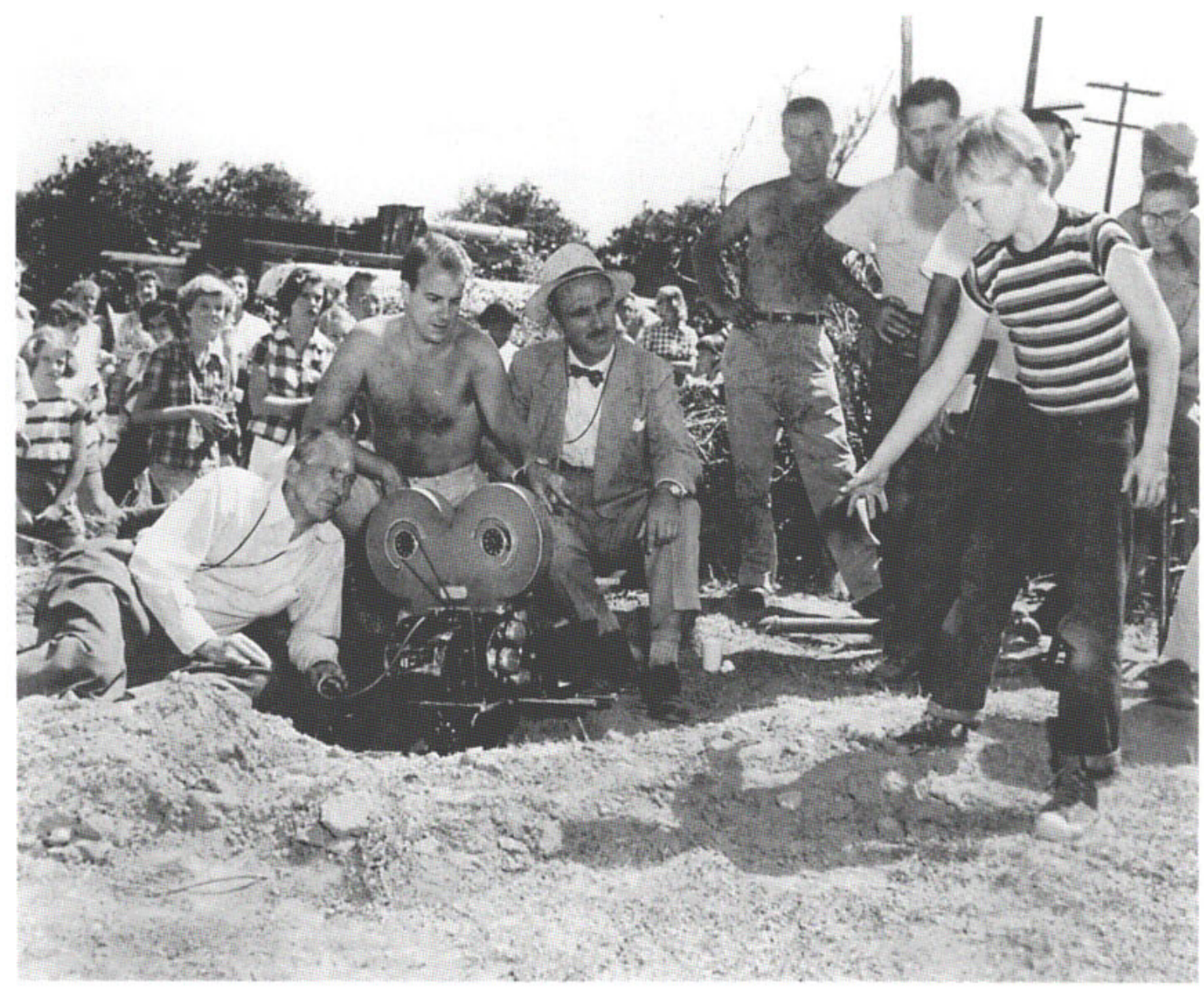

Fig. 7 Director David Bradley, without shirt, and John Alton, with hat, on the set of Talk about a Stranger. Print courtesy of David Bradley.

me up, but we were introduced and he was so charming, just fantastic. I liked his style very, very much, he was awfully good. This was supposed to be a big humiliation for him, this great man, pulled down and given to me. But nothing was too much trouble, nothing was impossible, it was perfect. We seemed to be like one person, and it became almost like father-son, even though I was going out with John Arnold's daughter."

Given this close perspective on and exposure to both sides in the conflict, Bradley was able to observe the pitched battle going on at MGM in the early 1950 s from an informed vantage point. "John Arnold went all the way back at MGM to The Big Parade, and that's the way he still thought things should be. When
Dore Schary started making lower-budget Bs at MGM, Arnold didn't like it, and he didn't like John Alton and all his dark stuff. There was a lot of friction around MGM between the Schary camp and the Mayer camp, a lot of relatives and friends who had embedded themselves at the studio and didn't want to change their ways." Talk about a Stranger turned out to be a modest little thriller with one striking, if very brief, visual sequence depicting a nocturnal chase through an orange grove lit entirely by smudge pots.

As for Richard Brooks, Alton first teamed with him on Battle Circus in 1953, and subsequently shot Take the High Ground, A Catered Affair, and The Brothers Karamazov for him at MGM. The latter film is quite rich visually, but 


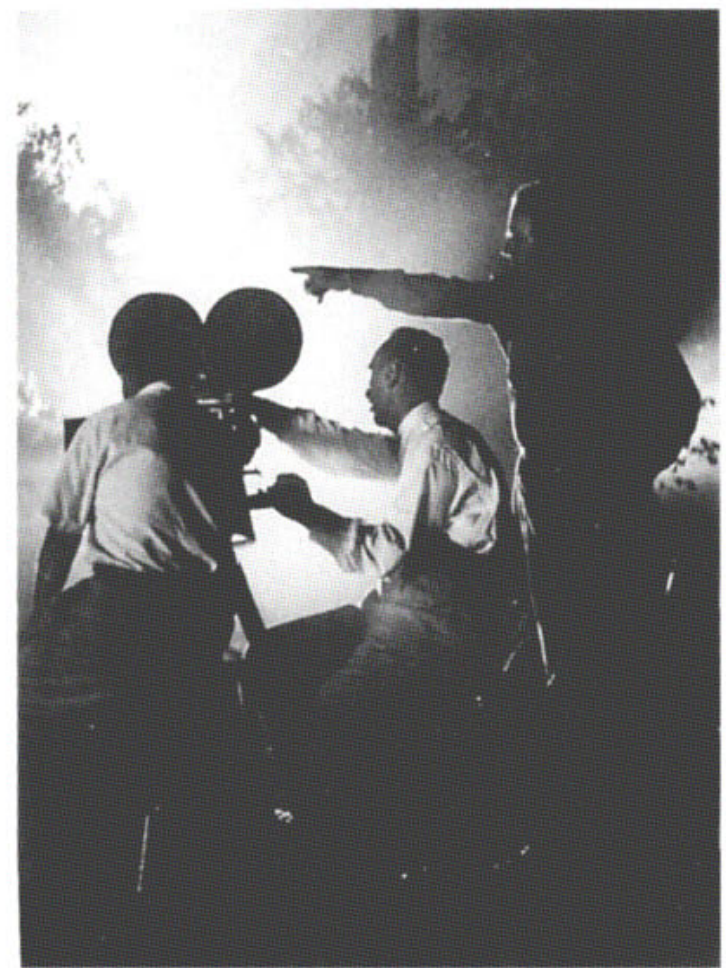

Fig. 8 John Alton, seated, during filming of Talk about a Stranger. Print courtesy of David Bradley.

does provide some telltale clues as to what his dissatisfied collaborators on Singin' in the Rain might have been complaining about: numerous scenes, particularly the interiors, are lit in utterly unrealistic ways, with lighting sources remaining quite unjustified and odd colors, notably purple, green, and yellow, bouncing off ceilings or bathing the characters in back light. The effects are sumptuous, glamorize the cast, and wouldn't be noticed by most viewers, but are a bit odd if you think about them. The affection and respect between director and cameraman was mutual. "I loved to work with Richard Brooks," Alton remembered. "He was so good."

By contrast, Alton retains less fond feelings for Allan Dwan, a veteran director whose long film career had started in 1909. They had worked together once at Republic, on the Western Driftwood in 1947, but during some of Alton's periodic vacations from MGM during the mid-1950s, they were paired seven times at RKO. Of Dwan, Alton said, "He was a big director at the beginning of the motion picture industry, but he didn't change, he didn't care or bring anything new to it, so that's why he fell off. But he was a good director." Although their overall quality ranges from excellent to mediocre, the first six of their 1950s films-Silver Lode, Passion, Cattle Queen of Montana, Escape to Burma (Fig. 9), Pearl of the South Pacific, and Tennessee's Partner-are suprisingly undistinguished visually coming from $\mathrm{Al}-$ ton. The last, however, Slightly Scarlet, in 1956, is a major noir, and arguably the best ever shot in color and widescreen (RKO's short-lived Superscope process). Saturated in reds (including the hair color of the two female leads) and blacks, the film features scenes of confrontation and violence that nearly match the tension and power of those Alton helped create in the late 1940s. Alton masterfully organized his pools of light to separate the characters and their competing interests. For examples of how Alton still sometimes seemed to put special effort into particular scenes, one need only look at the early sequence featuring mobster Ted de Corsia and his hoods, the follow-up scene between de Corsia and John Payne, and the climactic shoot-out.

Another notable loan-out during this period was for the Mickey Spillane thriller I, The Jury, whose single distinction is that it is the only film noir shot in 3-D (Fig. 10). Alton's signature lighting is clearly evident, but Harry Essex's direction is so inept, and takes so little advantage of the action's three-dimensional possibilities, that even a climactic fight on the exposed interior stairway of Los Angeles' Bradbury Building proves more laughable than exciting.

Still, Alton's crowning post-Oscar achievement was, ironically enough, a low-budget, down-and-dirty film noir. Arriving toward the end of the noir cycle in 1955, Joseph H. Lewis's The Big Combo was not seen as anything other than a cheap Allied Artists crime programmer at the time, but is now ranked by buffs 


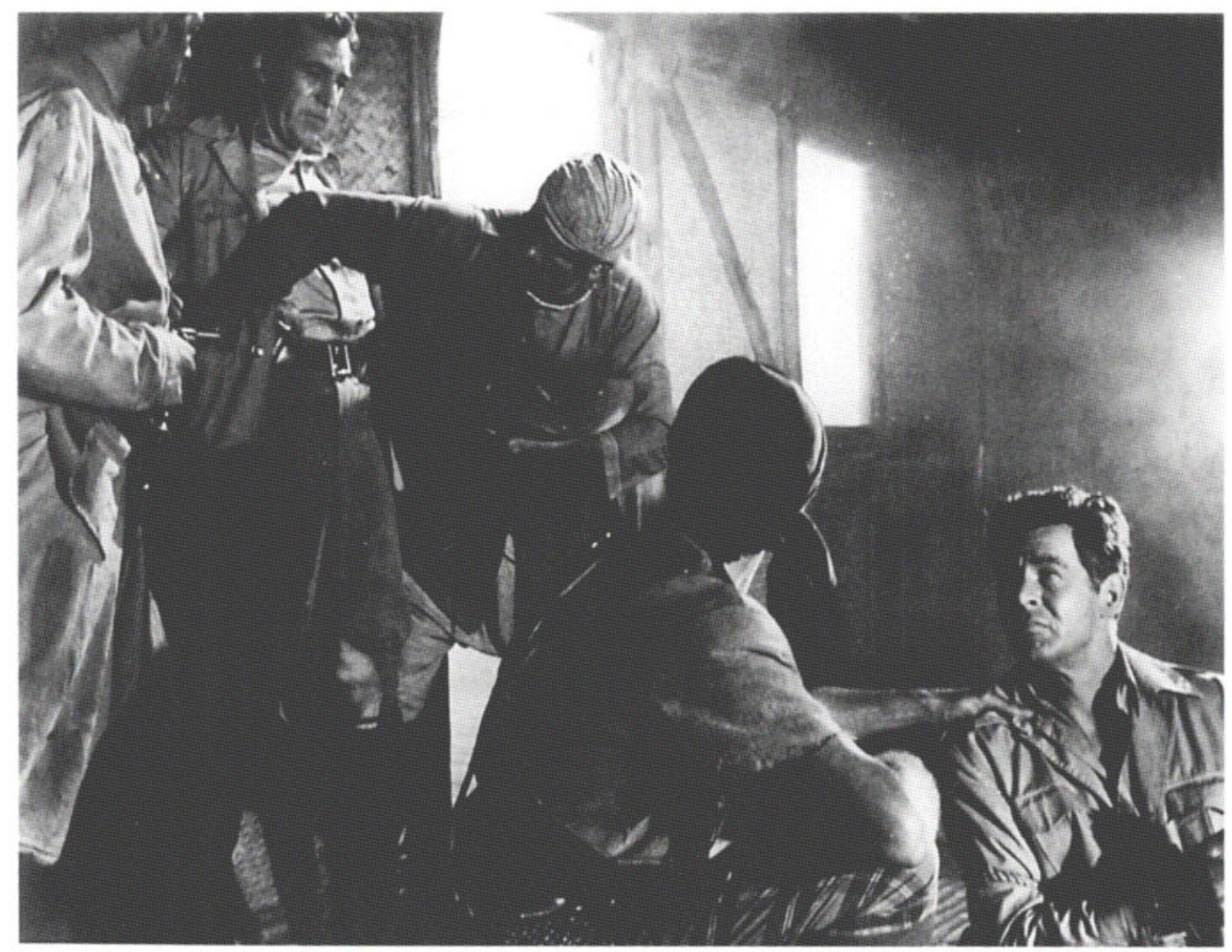

Fig. 9 Scene from Escape to Burma. Print courtesy of Museum of Modern Art Film Stills Archive.

and specialists as one of the top half-dozen or so noirs ever made (Fig. 11). One last time, Alton pushed his impulse toward severe blackand-white contrasts and silhouetting of characters to the limit. Many scenes are clearly lit with only one source, and the final shot, with the figures of a man and woman outlined in a warehouse against a foggy nightscape and illuminated by a single beacon, makes one of the quintessentially anti-sentimental noir statements about the place of humanity in the existential void. Perhaps the first scholarly American critic to single out Alton's work, Paul Schrader, in his 1971 essay Notes on Film Noir, argued that the cinematography of The Big Combo "is so nearly identical" to that of T-Men "that one has momentary doubts about the directorial differ- ences between Mann and Lewis. In each film light only enters the scene in odd slants, jagged slices and verticle or horizontal stripes." The Big Combo has influenced numerous contemporary directors and cinematographers, notably John Bailey and Allen Daviau. Bertrand Tavernier recalled that, "French critics in Cahiers du Cinéma and Positif, who had praised Alton since T-Men, now cited him as among Hollywood's greatest talents."

In 1958, Alton photographed Vincent J. Donehue's Lonelyhearts and Brooks's The Brothers Karamozov. In June 1959, he jumped back into the low-budget field to shoot a two-bit blackand-white science-fiction entry, 12 to the Moon, for his friend David Bradley. "John's enticement to work on it was my enthusiasm," Bradley 


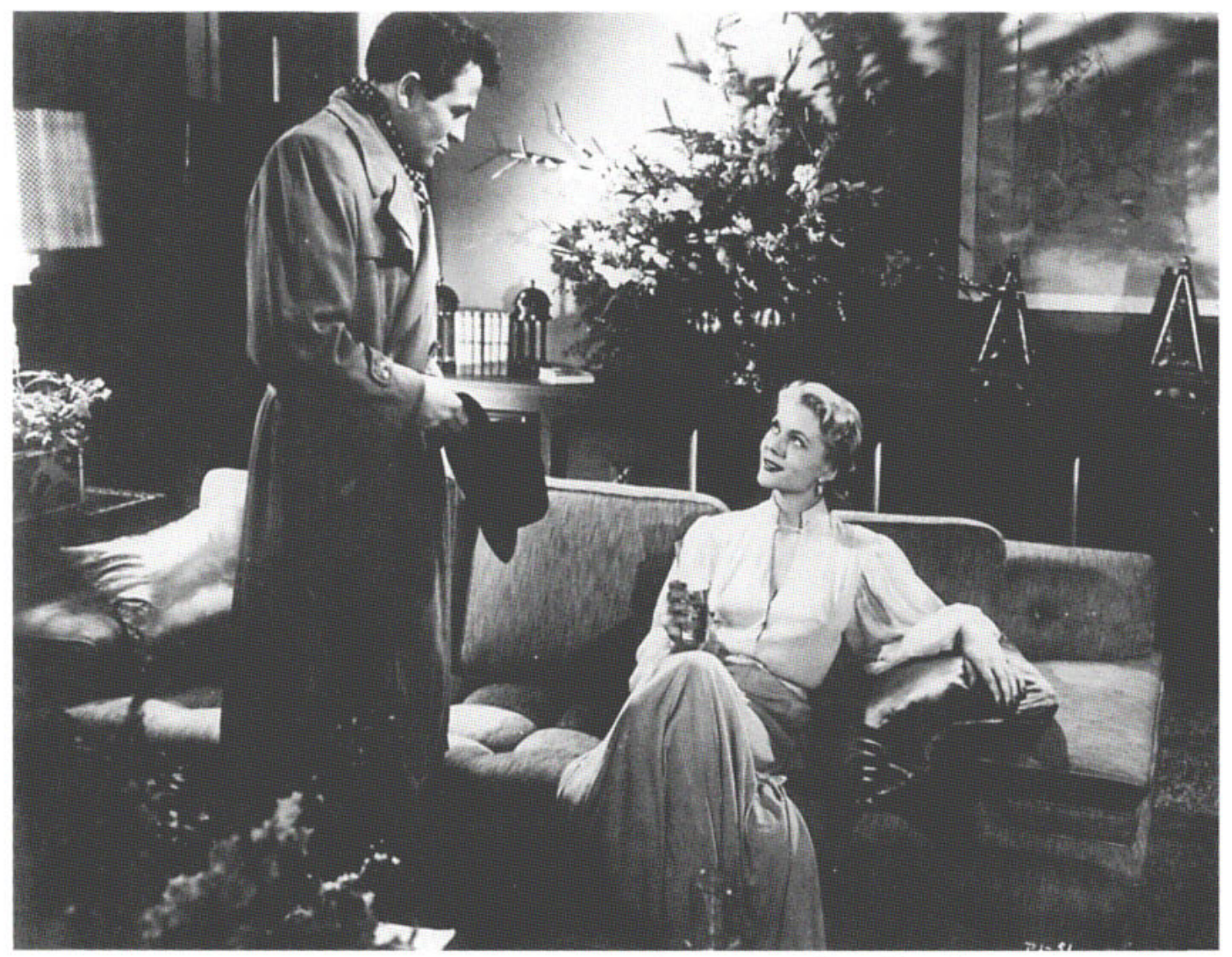

Fig. 10 Scene from I, the Jury. Print courtesy of Museum of Modern Art Film Stills Archive.

recalled, "plus the fact that we paid him much more than we would have anyone else. John was very interested in considering the light that would be on the moon, and he had never done a space picture." The patently artificial sets defeated any attempt Alton might have made to create uniquely lunar illumination, but the memorable opening sequence, which introduces the dozen international astronauts walking out of the fog toward their spacecraft, virtually picks up where the final shot of The Big Combo left off.

Alton immediately returned to the big time on Elmer Gantry, which shot through the fall of 1959. His splendid widescreen work on that picture, which was released the following summer, turned out to be his last. Reunited with Burt Lancaster, Alton started shooting Birdman of Alcatraz for British director Charles Crichton on November 7, 1960. After one week of shooting, Lancaster and producer Harold Hecht replaced Crichton with John Frankenheimer, but retained Alton. However, Frankenheimer could tell from the first moment that he and Alton were incompatible. "It lasted a day, or a day-and-a-half at the most," the director recalled. "It was just a conflict of personalities from the first day. It was just not my kind of shooting. He was used to working with directors who perhaps were not so specific as I was about how to shoot a scene, who let him do what he wanted. I knew I wanted a gritty, semidocumentary look, and he was lighting a lot of things that weren't even going to be in the shots. It was painful because I had great respect for him and I'm sorry it didn't work out. 


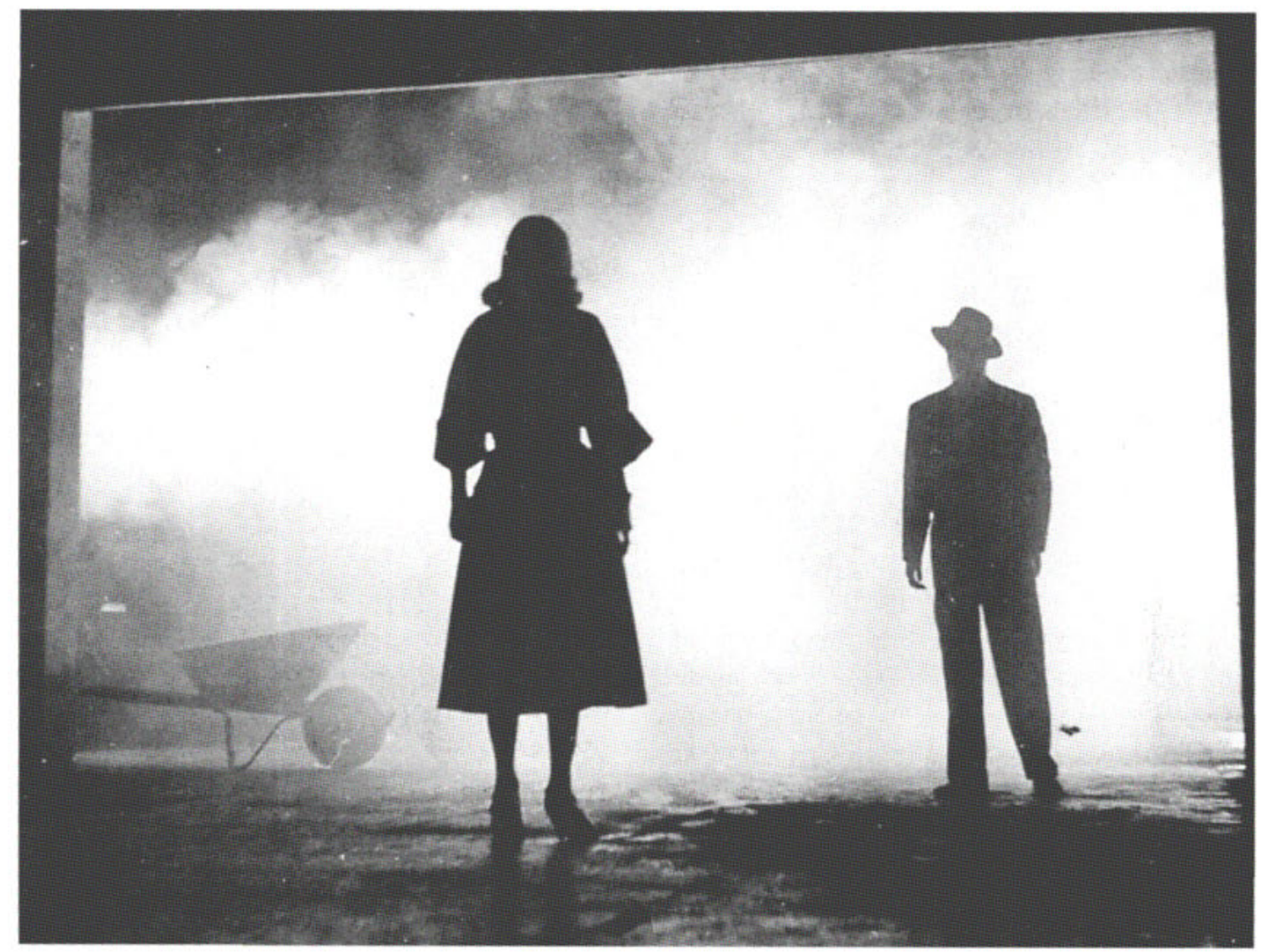

Fig. 11 Scene from The Big Combo. Print courtesy of Museum of Modern Art Film Stills Archive.

But I find that, if it doesn't work at the beginning, it's not going to get better." With this, John Alton had worked as a cinematographer for the last time, and none of his and Crichton's footage remains in the picture.

"He said what he wanted to do was go to Europe, to the Alps, and paint," said David Bradley, who kept up with Alton during this time. "That he'd done what he wanted to do, and he wanted to paint with brushes, not with light. He wanted to retire early. I'd see him when he came back to Hollywood once a year to keep up his citizenship standing."

Alton isn't entirely specific about why he quit his profession for good in 1960-his remarks about the years are marked by a mixture of pride, defiance, and bitterness, as well as satisfaction about the work he did. "I disappeared. I started traveling. I had a lot of money, about one million, and no children. I had three houses in Hollywood, and we sold one. My wife and I traveled, all through Europe, South America, the Amazon, Africa, and Asia. We never told anybody where we were, even the family." $\mathrm{He}$ did paint, "but I never had an ambition to be a professional painter. I always give them away to friends. If you have a toothache, as soon as you start painting, it stops. When you paint, you lose all pain through the concentration."

Still, from a professional point of view, his departure had to be painful. "The only mistake I made was quitting when I was 59," he confessed at a different moment. "The producers in those days were so shortsighted. I wanted to do quality. I thought about coming back later, but I found that the industry had changed."

So John Alton's abrupt exit from filmmaking, even if intended as temporary, turned into a 
permanent retirement, and thus did the mystery and legend begin. Critically and historically neglected, save for the odd noir specialist such as Schrader, through most of the 1960s and 1970 s, Alton was still "a bit of a legend with some of us at USC [University of Southern California] in the late 1960s," according to John Bailey. "It was the artistic stance he seemed to take toward his work. He created an aura of the artistic temperament. Like Gordon Willis in this generation, who thinks like an artist and isn't afraid to speak of himself that way, it was clear that here was a man who didn't consider himself just another worker bee in the studio system. Just as Gordon's work is so dramatic and different and so polarized generational feelings, so did John's. There were other wonderful cameramen who were doing excellent work in noir, such as Nicholas Musuraca, but I don't think they had quite the presentation, or personality, that John had. John's work didn't just call attention to itself, it did so aggressively. The style was more stark, more uncompromisingly severe than those of other people working around the same artistic area. If there's an Alton legacy, it's of the journey, and his own uncompromising aesthetic."

In 1979, Tom Luddy, codirector of the Telluride Film Festival, approached Alton to be the subject of a career tribute at that year's festival. Alton sent back a letter thanking him for the invitation to the Colorado festival but declined it due to "previous, uncancelable commitments" and unpredictable travel plans. "After I finished Elmer Gantry, I decided to take a well-earned vacation. This was in 1959, and am still enjoying it," Alton wrote.

Luddy and his Pacific Film Archive colleague Sally Armstrong tried again the following year, and Alton responded to the latter that, while in South America in 1979, "I became very ill, and was forced to return home. I am still very ill, and my condition was diagnosed as 'FUO,' (a jungle fever of unknown origin)." Writing to Luddy twice more in 1980, Alton elaborated on his many health problems, mused upon what
Darwin would make of the world today (he would write a book called The Decadence of the Species, he speculated), and begged off a festival appearance by saying that, "At present I seem to have more important priorities. I have my own 'Energy Problem,' that is, to regain my energy."

In this, Alton was to succeed tremendously. Although his wife Rozalia died without warning of heart failure in 1987, Alton met and married another woman, Billie Roberts, the following year. A year younger than Alton, she died in 1992.

Alton finally emerged into the public eye in February 1993. While making our documentary Visions of Light: The Art of Cinematography, my colleagues Arnold Glassman and Stuart Samuels and I had been frustrated in our attempts to secure an interview with Alton, but still included some examples of his work with Anthony Mann. Two days before the Los Angeles premiere, I received a call from Darren Weinstock, Alton's step-grandson, who informed me that Alton had read about the film in the Los Angeles Times and wanted to know if he could come see it. And so it was that John Alton received an ovation from a packed house in the presence of Conrad Hall, Haskell Wexler, Vilmos Zsigmond, Laszlo Kovacs, and about a dozen other luminaries in his field. (At the screening, Alton happened to sit across the aisle from an old Hungarian compatriot, director Andre de Toth; they had not seen each other since dining at the Little Prague restaurant in Hollywood more than fifty years before.)

Over Labor Day Weekend 1993, John Alton finally made the trip to the Telluride Film Festival, where audiences can only be said to have responded rapturously to the dazzling excerpts from his work and to his charming, somewhat mischievous personality. Slight and ever the bohemian in his ever-present beret, Alton held forth at two public question-and-answer sessions before hundreds of people, as well as at a smaller group discussion, and was approachable for more casual encounters throughout the 
weekend. He said that the mountain air and altitude made him feel more vigorous than usual, and he clearly thrived on the attention. After all, it was the first time in his life that he was in front of the public answering questions about his life's work. After avoiding it for so long, he loved it.

A month later, Alton flew to Austria to attend the Vienna Film Festival, which organized an impressive symposium on the enormous contributions of Viennese exiles to Hollywood, then proceeded to Israel, where he spent many weeks with his surviving sister, Esther. In January 1994, he received the Lifetime Achievement Award voted him by the Los Angeles Film Critics Association, and at the ceremonies met Steven Spielberg, who enthused at length about the veteran cinematographer's work. The San Francisco Film Festival held an Alton tribute in May, and the following month Alton traveled to New York to launch an extensive retrospective of his work at the Museum of the Moving Image in Queens. Alton has observed that, no matter where he goes, "It's a strange thing that, when I travel to all these festivals, they show all the small, dark pictures we made in 12 days, not the big pictures we took months to shoot."

Painting with Light began as a series of articles Alton began writing for International Photographer magazine in 1945. After many revisions and excisions, the book was bought by Macmillan and published in 1949 to good critical reception and sales. Still, the book may not have done Alton a lot of good within the industry, as it was offered as evidence that he held himself above others in his field, that he was a self-ordained expert on all matters photographic. As a proponent of using little light, he set himself up for attack from establishment traditionalists who regarded Alton's methods as crude, unsophisticated, even amateurish. American Cinematographer, which had spotlighted Alton so frequently over the years, took eight years to review the book, and even then

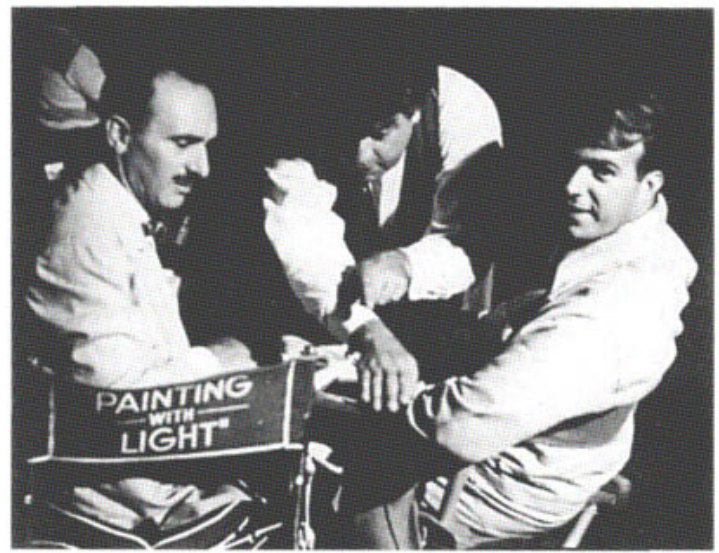

Fig. 12 John Alton, left, during filming of Talk about a Stranger. Print courtesy of David Bradley.

granted it only a qualified endorsement. The volume, the magazine stated in 1957 , is of "interest to the student cinematographer, but unfortunately it falls far short of the mark set by its title because the author has kept his text so concise as to be almost an abridgement" (Fig. 12).

In its 14 brief chapters, the book takes the reader through both the basics and refinements of motion picture photography, from elementary lessons about light sources to sophisticated notions about how to create very precise effects for specific artistic ends. The described means to achieve them, of course, are rooted in 1940s technology, and discussions of the equipment available are linked with the period when Alton was doing his most memorable work. As such, the book represents a trip back in time, a master class as taught by the industry's foremost iconoclast just as he was about to vault from successful obscurity to great renown within his profession. Recalling the profound impact Painting with Light had upon him as a student, Allen Daviau noted, "At the time the book came out, no one was going to tell you any secrets about cinematography, and he had instructions! It was the only case of an insider telling you what he did. It was a basic book from a master, and that was so important. This was the one and only book at the time that had some 'how to' to it. 
You just learned a lot of the tricks of the trade. The influence the book had on a whole group of us was tremendous-we studied cinematography through Painting with Light. Later, I enjoyed watching him break his own rules in some of his films. But because of the influence of the book, I've always looked at Alton as this teacher who also did these great films. So his impact as a cinematographer was doubled or tripled by the fact of this book."

For a contemporary student of cinematography, Painting with Light may be outdated in spots as far as the how is concerned; today, film is faster, cameras are smaller and more mobile, lenses are sharper, and, in the professional arena, there are not as many rules. But the what and the why are universal and not influenced by changing technology. Such issues as emotion and dramatic effect represent the essence of motion pictures, and Alton very clearly lays out how to master them strictly through the use of light and lens. The book is a lesson in basic, objective photographic wisdom, couched in a personal, idiosyncratic expression of principles and priorities. As such, it is to be treasured by anyone with even a passing interest in motion picture lighting and photography.

Looking back at 92, Alton observed, "As far as my life is concerned, if I had it to do all over again, I'd do it exactly the same. There are very few people that have the kind of success that I've had. When you enjoy your work, you live. I was very happy in what I did. In the morning, I always felt like a kid, going to the studio. It's what made my life a very fascinating life" (Fig. 13).

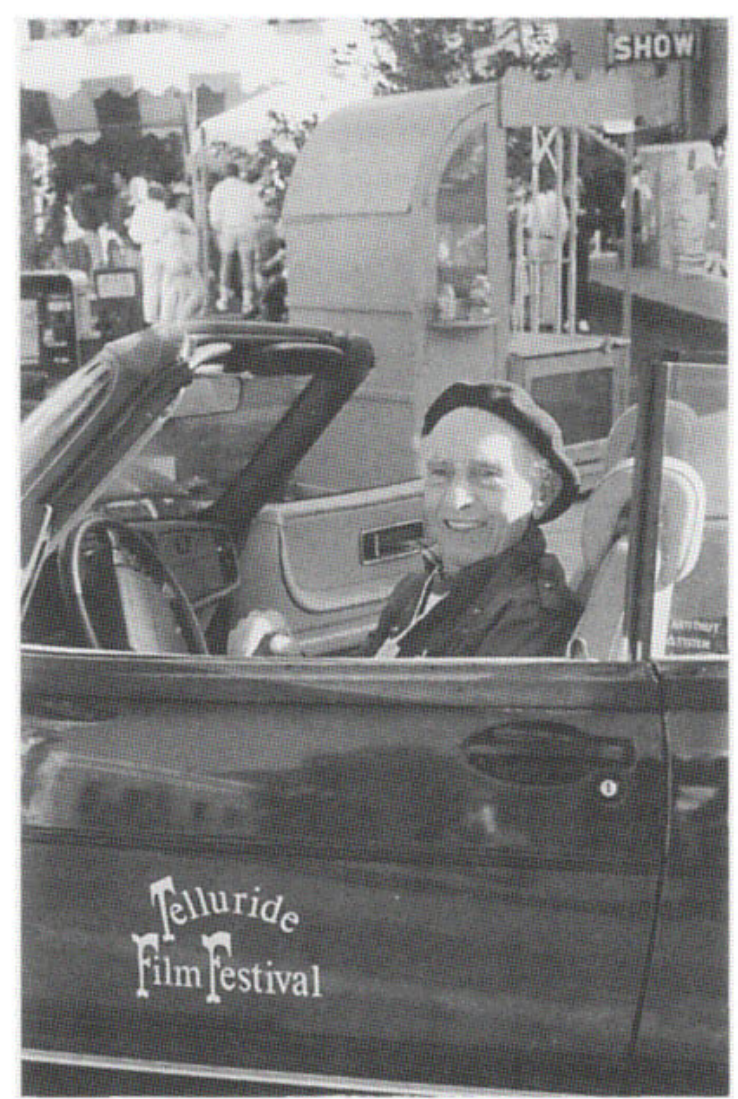

Fig. 13 John Alton at 1993 Telluride Film Festival. Print courtesy of Telluride Film Festival. 